\title{
Climate Crisis and the "We": An Essay in Deconstruction
}

\author{
Jan-Erik Lane* \\ Professor Emeritus at UNIGE, Geneva Switzerland
}

*Corresponding Author: Jan-Erik Lane, Professor Emeritus at UNIGE, Geneva Switzerland

\begin{abstract}
The new theory of abrupt climate change has yet to receive a response from those arguing for global policy coordination with the COP21 treaty or those who believe in country resilience. The only method to halt climate change with Hawking's irreversibiity is to cut CO2s sharply now. But it will not happen, because of human regidity, opportunism with guile and institutional inertia. The global powers, acting for "WE" or "US" concentrate all attention upon petty matters.
\end{abstract}

Keywords: Abrupt Climate Change, Tipping Points, Survival of Mankind, Illusion of "WE" Acting against Global Warming

\section{INTRODUCTION}

The new theory of abrupt climate change, drawing upon numerous so-called "tipping points", projects a dire future for mankind. Serious climate and earth scientists may go so far s to predict the coming end of the human species with billions of dead. Time is tight, according to some them, reducing the time span of 100 years figuring in the COP21 Treaty to just 10 years for "business as usual".

This predicament is attributed to "WE", asking what shall we do against this most dangerous threat against humanity ever? One may consult post-modern deconstruction theory to critique this widespread notion of "WE". Who are the real actors in this now unfolding drama?

\section{THE MENACE: HAWKING'S IRREVERSIBILITY}

Professor Chomsky has in his erudite speeches on YouTube compared global warming with nuclear confrontation as similar menaces. This is though hardly adequate, because run away climate change is worse. Nuclear confrontation is avoided by mutual arming and threat of annihilation. The Nash equilibrium is to swerve in a Chicken game. Global warming is not a game of interaction, but evolution. Evolution has a different logic - Hawking irreversibility and not rational human calculation as in gaming interaction.

Nuclear armament is very expensive and totally meaning for both parties when they pursue the very same strategy. Iran and Saudi Arabia should make a deal to stop nuclear proliferation and invest in ecology. Run away climate change lacks a set of actors in interaction, because it is Nature simply with its colossal forces.

So, can "WE" stand up against global warming, with global coordination and policy-making and implementation? No, because there is behind the "WE" a great multitude of different actors with opposing interests: civil society organisations, governments, business, financial institutions, and ordinary people. Some groups in the set of humans make money on global warming, whereas other groups loose assets. Some rise their voice, while others look the other way. Bjorn Lomborg as the only remaining cornucopian (Planet Earth can accommodate has yet to understand the issue.

The truth is:

a) global warming is driven by an incredibly insatiable need for energy;

b) Global coordination does not work - transaction costs and defection:

c) Country resilience is lower than many believed, as Nature has the upper hand.

These points are often bypassed by natural scientists, but they can be stated clearly in the social sciences. 


\section{ENERGY NEEDS}

Thus, energy consumption is closely related to country affluence. The poor countries can only improve living condition by increase energy supply. Their energy demand can only go up, because energy supply is highly skewed to the advantage of the rich countries, but they emit most CO2s - see Figure 1.

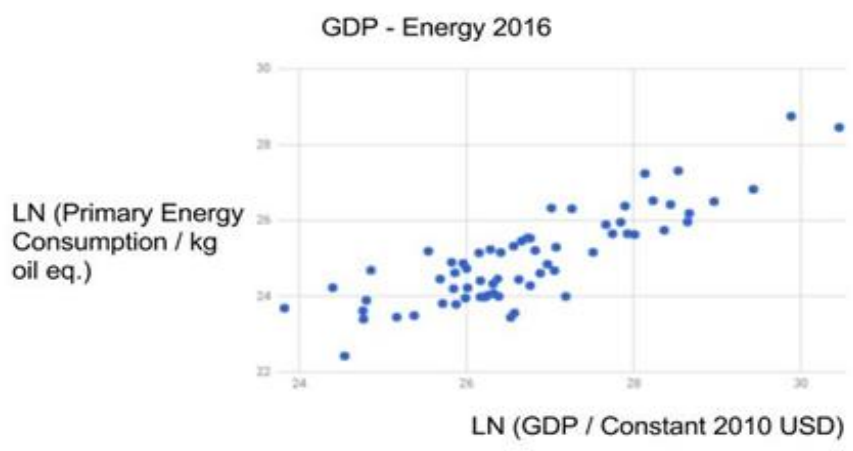

Figure1. Energy and affluence globally

Energy is the capacity to do work. And work is the Adam Smith and J-B Say sources of human welfare. The growth in energy consumption since the industrial revolution and especially after the Second World War has been just immense, especially the supply of fossil fuels. In poor countries, the demand for energy is huge for economic development toward "catch-up", whereas rich countries are heavily dependent of fossil fuels for economic growth. The majority of countries in the COP project are in poverty, as they need more energy. Thus, they can only decarbonise when renewable energy sources become available. This is the redistribution task of C0P21: decarboisation against support for renewable energy by the Super Fund.

The majority of countries in the COP project are in poverty, as they need more energy. Thus, they can only decarbonise when renewable energy sources become available. This is the redistribution task of C0P21.

The living conditions in the poor countries in Latin America, Africa and Asia as well as the Pacific reflect the low level of energy employed. This basic fact determines life opportunities in a most dramatic fashion. The low access to energy has consequences for the environment and the life situation of people, including health, schooling, work, food and potable water.

African countries are poor because they have too little energy. Thus, they have much less GHGs than Asia. Yet, they need the COP project of the UNFCCC to renew their energy sources and move from fossil fuels and traditional renewables to solar power. Hydro power depends upon water availability that shrinks with global warming.

African energy deficit is conducive to a dire environment with enormous damages and risks. Consider the following global figures. Figure 2 shows how low energy leads to am unsafe environmental.

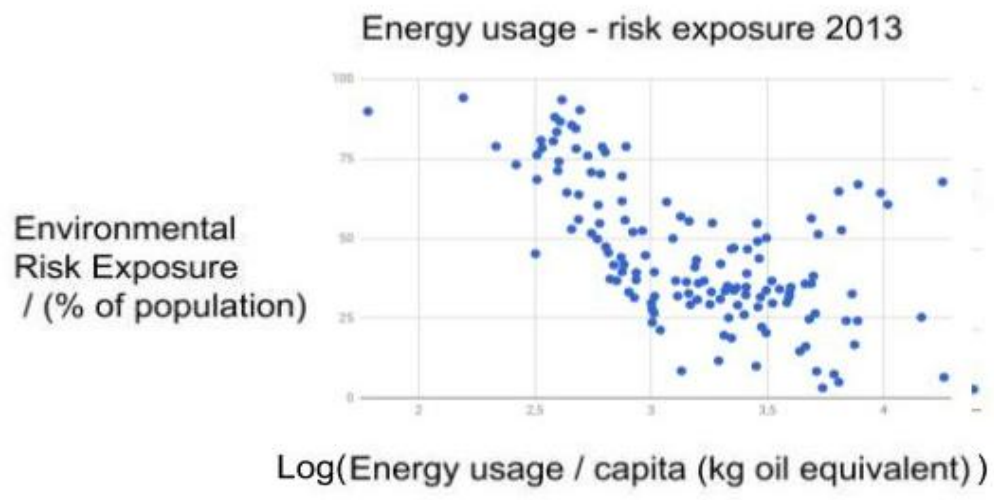

Figure2. Energy and environmental risk exposure

Source: Environmental Performance Index, Yale University, https://epi.envirocenter.yale.

IEA Statistics @ O OECD/IEA 2014 (http://www.iea.org/stats/inde) 
Low energy use leads to poverty, malnutrition, deceases, lack of potable water, insufficient sanitation, etc. Typical of many Latin American, African and Asian nations is the lack of stable electricity, which hampers everything and reduces environmental viability. Figure 3 has the global picture.

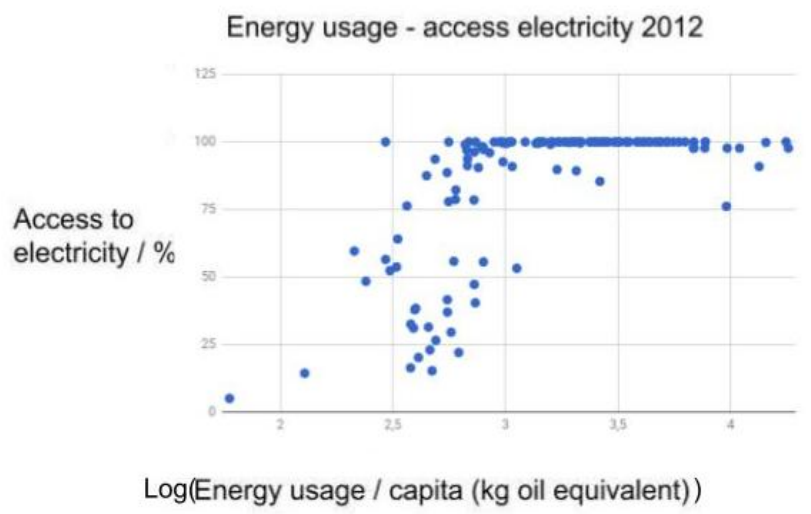

Figure3. Energy and electricity access

Source: Environmental Performance Index, Yale University, https://epi.envirocenter.yale.

IEA Statistics @ OECD/IEA 2014 (http://www.iea.org/stats/inde)

The access to safe and stable electricity is crucial for health, schools, food, water, etc. Figure 4 links energy with proper sanitation.

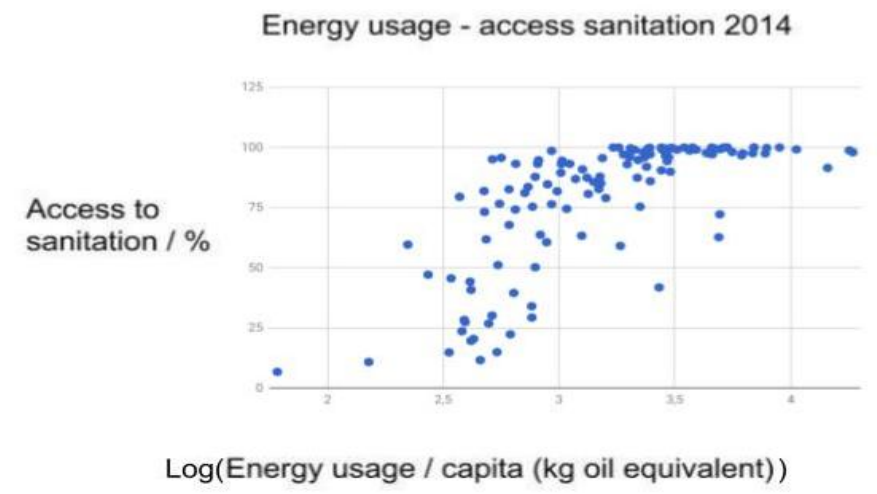

Figure4. Sanitation and energy

Source: Environmental Performance Index, Yale University, https://epi.envirocenter.yale.

IEA Statistics @ OECD/IEA 2014 (http://www.iea.org/stats/inde)

Especially, the rapidly growing African and Asian mega-cities lack entirely sewage plants. Thus, dirty water is put into the big rivers where other cities downstream take their potable water.

The access to safe and stable electricity is crucial for health, schools, food, water, etc.

Figure 4 links energy with proper sanitation.

Figure 5 underscores the necessity of more energy in poor coutries.

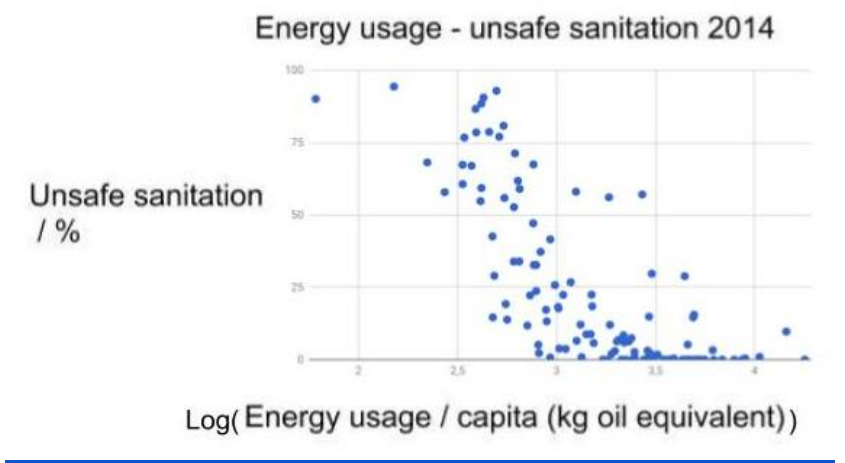

Figure5. Energy and unsafe sanitation

Source: Environmental Performance Index, Yale University, https://epi.envirocenter.yale.

IEA Statistics @ OECD/IEA 2014 (http://www.iea.org/stats/inde) 
Air quality too depends upon energy access (Figure 6).

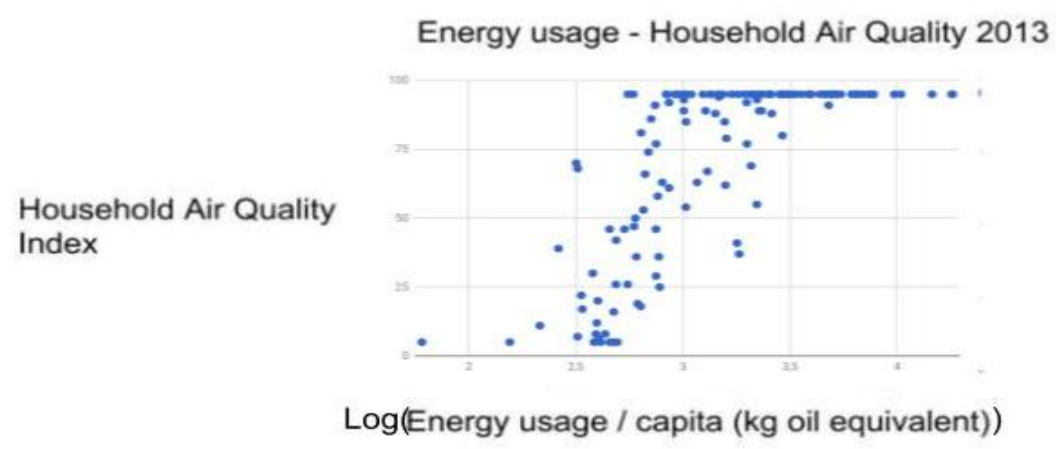

Figure6. Energy and air quality

Source: Environmental Performance Index, Yale University, https://epi.envirocenter.yale.

IEA Statistics @ OECD/IEA 2014 (http://www.iea.org/stats/inde)

Typical of many poor nations - Latin America, Africa, Asia - is the lack of stable electricity, which hampers work and reduces environmental viability. The access to safe electricity is crucial for health, schools, food, water, etc. Given the lack of enough energy in poor countries being conducive to the above bad living conditions, one understands the hopes of the poor countries for help with energy transformation leading to better access to just energy

In terms of GHGs, rich countries have much higher levels of yearly emissions compared with poor countries, holding population constant. Only when a poor country has an enormous population is it a big CHG polluter.. Strict linear relation holds between GDP, energy consumption

If, as we believe, energy consumption is behind global warming, the set of poor countries face a most difficult dilemma. On the one hand, they can demand much more energy like fossil fuels, but they then contribute much to climate change, On the other hand, global warming while fabricated by the rich nations and a few very populous poor nations, will have very negative consequences for poor nations. The only way out of this dilemma is that all countries contribute to halting global warming by turning to renewables, especially the set of rich countries.

The figures above present a summary of the human development theory with its UN sanctioned HDI measure - human development index. Poor nations and emerging economies know all too well that their developmental goals depend upon access to cheap. Thus, they will never accept global decarbonisation if they must give up fossil fuel energy without compensation.

Several poor nations strive for "take-off" and the emerging economies go for "catch-up" at any cost. They demand assistance for achieving some form of decarbonisation. So they were promised a Super Fund of 100 million dollars per year - where is it?

The advanced economies accept decarbonisation, only it can be combined further economic growth. Energy gives affluence and the climate change problematic. Can the COP21 project succeed?

\section{L Policy MaKing AND IMPlementation: Some FAllaCieS}

As a matter of fact, a few dominant theoretical frameworks doubt the achievebility of major policymaking and implementation project. Let us consult them with regard to the COP21 endeavors.

\subsection{Bounded Rationality (Simon And March)}

Simon and March (1958) would have e had no difficulties in rejecting the COP21 project as not fitting the rational decision-model. He would point out the cognitive limitations in the project:

a) No comprehensiveness: COP21 bypasses one major GHG, namely methane. If lots of methane are released in the Arctic, COP21 will fail no matter what;

b) Ambiguity of objectives: what is the sense of "decarbonisation" when no specific targets are set in absolute numbers that are observable and verifiable?

c) Absence of control mechanisms like oversight, incentives (positive or negative) and mere promises without sanctions. 
Simon argues that only bounded rationality or restricted decision-making is feasible, both for single individuals and organisations or groups. Especially organisations pursue "standard operating procedures", according to March, meaning simplifications of the requirements of full rationality, as laid down by the neo-classical decision model in economics. As a matter of fact, the arrival of abrupt climate change makes the COP21 project already outdated.

\subsection{Implementation Gap (Wildavsky)}

Scholars with the discipline of public administration follow the teachings of A. Wildavsky (Pressman and Wildavsky, 1984) about an inescapable gap between policy ex ante and implementation ex post. Implementation theory was developed for national policy-making with finding of a major gap between blue-prints in the centre and implementation failure at the local or regional levels. Policymakers engaging in nation-wide programs face bounded rationality. Thus, each and every national policy includes uncertainty and has to be adapted or changed locally.

The same policy - implementation gap applies to international relations where coordination efforts are not only hampered by bounded rationality but also the restrictions from public international law, especially the principle of state sovereignty.

The COP21 Treaty may have been a great leap forward from one point of view, namely environmentalism as philosophy, but the entire COP21 project face enormous implementation difficulties, as policies are vague and management lacking.

\subsection{Organised Chaos (March And Olsen)}

In the theory of organisation, one has been very interested in the possibility of groups of people to engage in rational action, like the governments of the world setting up a plan for global decarbonisation. The answer is that individual rationality may be feasible at the micro level, but large organisation with many decision-makers must fail at the macro level. There will be simply too much conflict, confusion, mistakes, lack of consistency over time ${ }^{-}$in one word chaos. In organised collective action, leadership is luck, preferences changing and information biased.

Judging the COP21 Treaty from the perspective of March and Olsen (1976), launching their conception of government as organised chaos, one may have serious doubts about the implementation of the COP21 project. A promise is made of giant money in a Super Fund, but how to fund it? Global decarbonisation is set out in three main stages, but it is a too slow process with many loopholes. And the conflicts among states are deep concerning which countries should do the most and contribute the most to the Super Fund.

\section{Global CoORdination: Transaction COSTS}

The UN has conducted no less than 23 COP global meetings besides the standing agency IPCC, but decarbonisation has NOT begun. CO2s are still increasing 2017, globally. Inter-state decision-making faces almost insurmountable difficulties, according to international relation theory.

\subsection{Reneging or Cheating}

Even if one accepts that the COP21 project is rational or semi-rational decision-making (clear preferences, reasonable technology, game theory would warn that it is wide open to strategic behaviour and asymmetric information. It does not matter it is micro level or macro level choice, as both individual and collective decision-making can be cheated upon by reneging upon promises (Dutta, 1999).

The COP21 Treaty is nothing but a paper with promises for a very long time and with enormous practical consequences. Why deliver upon it? Energy transformation is costly and affect ordinary people. When costs go up, maybe defect from promises made a time ago? Or demand a hefty compensation from the Super Fund?

The paradox of the famous PD game lies at the core of the COP21 project. It is rational for each single participant in the common pool regime (CPR) to defect hoping that the others will deliver $(\mathrm{N}-1$ problem) or to delay contributing because the benefits will be shared by others ( $1 / \mathrm{N}$ problem). The US has already reneged because the Trump administration does not to contribute to the Super Fund or India's decarbonisation costs. As the COP21 project moves along, there will be many opportunities for defection, especially as the PIL sanctions this. 


\subsection{International Society Versus Anarchy of States}

The COP21 Agreement enters public international law, when it has been ratified by the UN member states. Scholars have held great hopes about the PIL, restraining state sovereignty. But it is only forcing governments when it comes to the questions of war and peace, where the Security Council rules if unanimous. Rule of rule in an international society has not yet accomplished, meaning that several treaties of PIL can be reneged upon, like the COP21 Treaty. Governments tend to first and foremost act upon national interests, even when it foes against international norms (Burchill, Linklater and Devetak (2013).

\section{ReSilienCE: FAlSE Promise of Adaptation}

In the great debates between environmentalists and cornucopians as well as around the precautionary principle, the position of resilience was developed by economists and policy analysts. It contains:

- do not look for possible ecology disasters ex ante;

- wait and see what happens;

- take proper action ex post;

- do not exaggerate ecological harm;

- build up resources for remedies;

- do not prevent improbable ecological damages;

- always take action afterwards on correct information.

The principle of resilience rejects the principle of precaution. It is based upon a risk approach that underlines probabilities. Even if the possible damage is huge but the probability is low, do nothing, just wait and see. Resilience is much in tone with bounded rationality: What do You really know for certain?

Its main spokesmen were Wildavsky (1988) earlier and Lomborg (2007) now.

Resilience may give more GHGs. Take China: “Take-off” point me around 1980 pursuing a successful "catch-up" policy for a few decades. Its energy consumption, especially fossil fuels, has skyrocketed with GDP, resulting in the largest $\mathrm{CO} 2$ emission globally. Figure 7 has a projection for China.

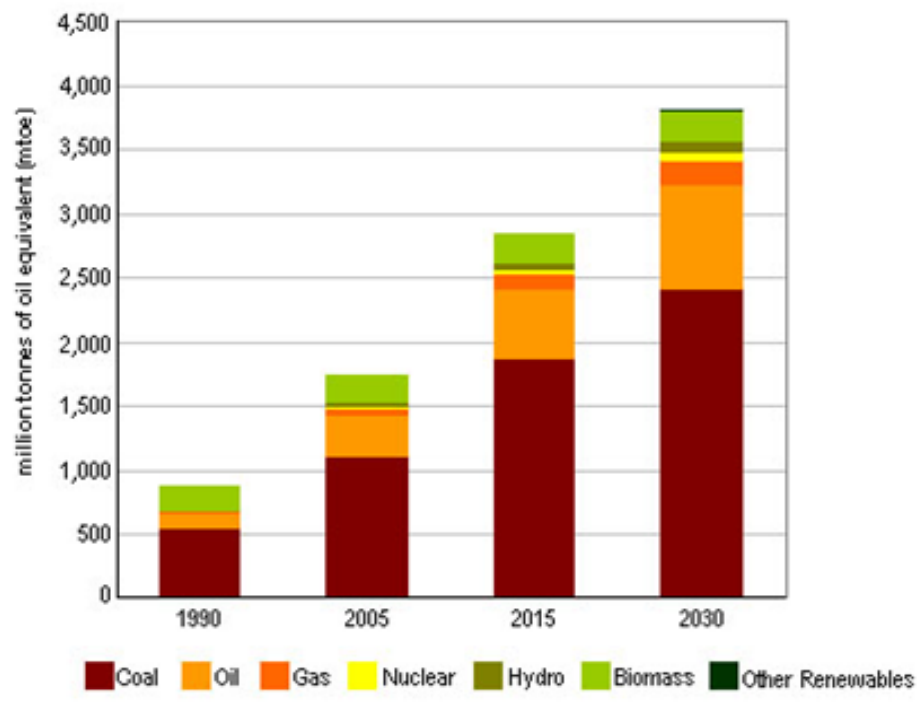

Figure7. Energy projection for China

http://www.wrsc.org/attach_image/chinas-projected-energy-growth-fuel

Decarbonisation does not seem highly probable. Much hope was placed at a recent reduction in $\mathrm{CO} 2 \mathrm{~s}$, but water shortages forced China to revert to coal in 2017 with attending augmentation of CO2s. China is investing in both renewables and atomic power, but it also plans for very large energy increases in the coming decades with lots of energy consuming for new huge projects. 
It is true that the US has reduced its $\mathrm{CO} 2$ emissions during the lats years, mainly by a shift from coal to natural gas. Actually, several mature economies like e.g. the UK have been able to halt the rise of $\mathrm{CO} 2$ emissions, either by more energy efficiency or a shift to natural gas or renewables. Figure 8 captures some features in US energy plans.

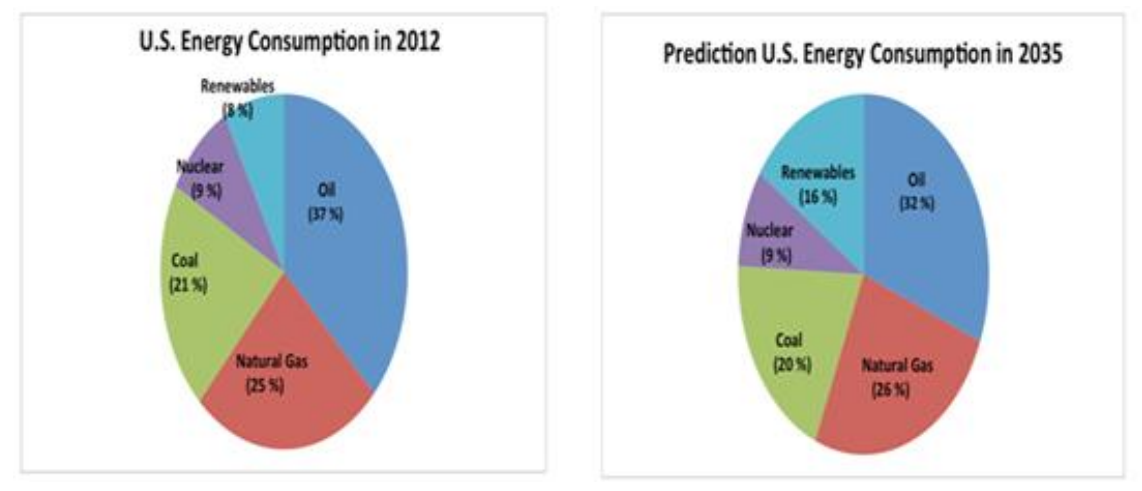

Figure8. US energy future

Source: https://www.e-education.psu.edu/egee102/node/1930

Although the Figure 8 predicts a doubling of renewable energy, the dependency upon fossil fuels, including coal energy, will not be much reduced. We are talking here about relative numbers, but if the US increases total amount of energy supply, then there may even be more fossil fuels. The reduction in $\mathrm{CO} 2$ s during recent years seems to be coming at a reduced rate. The hope is for economic growth without energy increases, but we are not there yet. And most countries demand much more energy for the future.

Resilience could be a promising risk strategy, only when the threat is not fully known or manageable. Abrupt climate change falls outside of these requirements!

Among some climate scientists, there is recently a new urgency. The melting of the North polar ice is advancing so quickly that all projections about temperature rise on the Earth must be revised upwards. Quicker warming sets in motion very positive feedback $s$ that threaten human survival. The goal of COP21 - limit global warming to +2 degrees Celsius - is no longer achievable. Instead, climate chaos seems more likely. A few predict that mankind has no more than 10 years before things become unmanageable. When the North pole ice is gone, global warming goes much higher than +2 .

The theory that climate change is now becoming irreversible is based on new hypotheses concerning the consequences of global warming:

- sea level rise and Arctic ice meltdown is quicker than believed;

- climate refugees may rise to 100 million people;

- food and water shortages come earlier than believed;

- the +2 degrees Celsius target is misplaced as the Earth warms differently at various regions, i.e. still much hotter at the poles;

- the release of methane from the permafrost and the frozen ice at the North pole will bring temperature rise to +10 degrees Celsius;

As the potentially huge methane emissions enter the climate change debate, one fully understands the mounting pessimism. And the entire time scale for fighting global warming shrinks considerably, from 100 years to 50 years or even less.

\section{REALISTIC SOLUTION VERSUS UTOPIAN}

One may outline a more radical COP21 policy and ask for its implementation to start now:

- Close down of all coal power plants in 2020; replacement of charcoal in poor countries by mini gas stoves;

- Massive investments in solar power parks - see below; subsidies for solar installations in private homes;

- Accelerated experiments with carbon capture to find accurate cost-benefit calculation. 
Here comes the solar power revolution that will allow a massive reduction in fossil fuels. Let us see what it entails in terms of management tasks for global coordination, assisted by for instance the COP21 Secretariat and the IPCC.

Table1. Number of Ouarzazate plants for 40 per cent reduction of CO2 in some giant countries (Note: Average of 250 300 days of sunshine used for all entries except Australia, Indonesia, and Mexico, where 300 - 350 was used).

\begin{tabular}{|l|l|l|l|}
\hline Nation & $\begin{array}{c}\text { Co2 reduction pledge / } \\
\text { \% of 2005 emissions }\end{array}$ & $\begin{array}{c}\text { Number of gigantic solar } \\
\text { plants needed (Ouarzazate) }\end{array}$ & $\begin{array}{c}\text { Gigantic plants needed } \\
\text { for 40 \% reduction }\end{array}$ \\
\hline United States & $26-28$ & 2100 & 3200 \\
\hline China & none & 0 & 3300 \\
\hline EU28 & $41-42$ & 2300 & 2300 \\
\hline India & none & 0 & 600 \\
\hline Japan & 26 & 460 & 700 \\
\hline Brazil & 43 & 180 & 170 \\
\hline Indonesia & 29 & 120 & 170 \\
\hline Australia & $26-28$ & 130 & 190 \\
\hline Russia & none & 0 & 940 \\
\hline World & N/A & N/A & 16000 \\
\hline
\end{tabular}

Note: I) The United States has pulled out of the deal; ii) No absolute target; iii) Pledge is above current level, no reduction; iv) Upper limit dependent on receiving financial support; v) EU joint pledge of $40 \%$ compared to 1990.

It will of course be argued against such a 40 per cent speedy reduction in $\mathrm{CO} 2 \mathrm{~s}$ that it leads to economic recession. So may it be! But it would reduce future much higher costs. After all, economies adapt and will recover due to all new investments needed in a decarbonised world. Ramesh (2015) emphasizes that India needs much economic assistance for decarbonisation - a giant task for global coordination to assist poor nations!

Let us look at the American scene in Table 2.

Table2. Number of Ouarzazate plants necessary for 40 per cent reduction in CO2 (Note: Average of 250 - 300 days of sunshine per year was used for Canada, 300 - 350 for the others).

\begin{tabular}{|l|l|l|l|}
\hline \multicolumn{1}{|c|}{ Nation } & $\begin{array}{c}\text { Co2 reduction pledge / } \\
\text { \% of 2005 emissions }\end{array}$ & $\begin{array}{c}\text { Number of gigantic solar } \\
\text { plants needed (Ouarzazate) }\end{array}$ & $\begin{array}{c}\text { Gigantic plants needed } \\
\text { for 40 \% reduction }\end{array}$ \\
\hline Canada & 30 & 230 & 300 \\
\hline Mexico & 25 & 120 & 200 \\
\hline Argentina & none & 0 & 80 \\
\hline Peru & none & 0 & 15 \\
\hline Uruguay & none & 0 & 3 \\
\hline Chile & 35 & 25 & 30 \\
\hline
\end{tabular}

Note: I) The United States has pulled out of the deal; ii) No absolute target; iii) Pledge is above current level, no reduction; iv) Upper limit dependent on receiving financial support; v) EU joint pledge of $40 \%$ compared to 1990.

Some Latin American countries have lots of hydro power, but it may dwindle rapidly due to abrupt climate change. Solar power would be excellent energy for Mexico and Brazil for example.

Table 3 has the data for the African scene with a few key countries, poor or medium income. As they are not in general energy consuming on a grand scale, like Asia, decarbonisation should be feasible with Super Fund support.

Table3. Number of Ouarzazate plants necessary in 2030 for 40 per cent reduction in CO2 (Note: Average of 300 - 350 days of sunshine per year was used).

\begin{tabular}{|l|l|l|l|}
\hline \multicolumn{1}{|c|}{ Nation } & $\begin{array}{l}\text { Co2 reduction pledge / } \\
\text { \% of 2005 emissions }\end{array}$ & $\begin{array}{c}\text { Number of gigantic solar } \\
\text { plants needed (Ouarzazate) }\end{array}$ & $\begin{array}{c}\text { Gigantic plants needed } \\
\text { for 40 \% reduction }\end{array}$ \\
\hline Algeria & $7-22$ & 8 & 50 \\
\hline Egypt & none & 0 & 80 \\
\hline Senegal & $5-21$ & 0,3 & 3 \\
\hline Ivory Coast & $28-36$ & 2 & 3 \\
\hline Ghana & $15-45$ & 1 & 3 \\
\hline Angola & $35-50$ & 6 & 7 \\
\hline Kenya & 30 & 3 & 4 \\
\hline Botswana & 17 & 1 & 2 \\
\hline
\end{tabular}




\begin{tabular}{|l|l|l|l|}
\hline Zambia & $25-47$ & 0,7 & 1 \\
\hline South Africa & none & 0 & 190 \\
\hline
\end{tabular}

Note: I) The United States has pulled out of the deal; ii) No absolute target; iii) Pledge is above current level, no reduction; iv) Upper limit dependent on receiving financial support; v) EU joint pledge of $40 \%$ compared to 1990.

Table 4 shows the number of huge solar parks necessary for a few Asian countries.

Table4. Number of Ouarzazate plants necessary for 40 per cent reduction in CO2s. (Note: Average of 250 - 300 days of sunshine was used for Kazakhstan, 300 - 350 days of sunshine per year for the others).

\begin{tabular}{|l|l|l|l|}
\hline \multicolumn{1}{|c|}{ Nation } & $\begin{array}{c}\text { Co2 reduction pledge / } \\
\text { \% of 2005 emissions }\end{array}$ & $\begin{array}{c}\text { Number of gigantic solar } \\
\text { plants needed (Ouarzazate) }\end{array}$ & $\begin{array}{c}\text { Gigantic plants needed } \\
\text { for 40 \% reduction }\end{array}$ \\
\hline Saudi Arabia & none & 0 & 150 \\
\hline Iran & $4-12$ & 22 & 220 \\
\hline Kazakhstan & none & 0 & 100 \\
\hline Turkey & 21 & 60 & 120 \\
\hline Thailand & $20-25$ & 50 & 110 \\
\hline Malaysia & none & 0 & 80 \\
\hline Pakistan & none & 0 & 60 \\
\hline Bangladesh & 3,45 & 2 & 18 \\
\hline
\end{tabular}

Note: I) The United States has pulled out of the deal; ii) No absolute target; iii) Pledge is above current level, no reduction; iv) Upper limit dependent on receiving financial support; v) EU joint pledge of $40 \%$ compared to 1990.

Given the economic advances in Asia, most countries need a lot of solar power parks for decarbonisation. The COP21 management would be able to help.

Finally, we come to the European scene.

Table5. Number of Ouarzazate plants necessary for 40 per cent reduction in CO2s (Note: Average of 250 - 300 days of sunshine per year was used)

\begin{tabular}{|l|l|l|l|}
\hline \multicolumn{1}{|c|}{ Nation } & $\begin{array}{c}\text { Co2 reduction pledge / } \\
\text { \% of 2005 emissions }\end{array}$ & $\begin{array}{c}\text { Number of gigantic solar } \\
\text { plants needed (Ouarzazate) }\end{array}$ & $\begin{array}{c}\text { Gigantic plants needed } \\
\text { for 40 \% reduction }\end{array}$ \\
\hline Germany & 49 & 550 & 450 \\
\hline France & 37 & 210 & 220 \\
\hline Italy & 35 & 230 & 270 \\
\hline Sweden & 42 & 30 & 30 \\
\hline
\end{tabular}

Note: I) The United States has pulled out of the deal; ii) No absolute target; iii) Pledge is above current level, no reduction; iv) Upper limit dependent on receiving financial support; v) EU joint pledge of $40 \%$ compared to 1990.

It may be tempting to combine climate change with other issues, like general environmental degradation and the quest for a sustainable economy or social equity. Sachs may speak of the age of sustainability, but is just a figment of the imagination. Nothing is durable. European nations dismantle nuclear power stations at horrendous costs, but keep employing fossil fuels, even coal. The risks with global warming outweigh those of nuclear power debacle. Japan had 52 nuclear stations, but now only 2. What to do? LNG just as South Korea? Brazil plans to turn the Amazons into a park of hydro power dams, but the fresh water of the world is rapidly shrinking.

If the egalitarian discourse of among others Piketty, Stiegler and Sen is combined with the climate change or environmental degradation issues in a final search for sustainability, then only conflict is the outcome.

\section{CONCLuSion}

The "WE" in the global warming is a myth, as different groups collide over climate change response with their special "stories". Global warming can only be halted by somehow reducing quickly the CO2s. It will not happen, either in global or through country resilience. The G20, responsible for $70 \%$ of the $\mathrm{CO} 2 \mathrm{~s}$, occupies itself with other "petty" issues, or some of them are hardly capable of facing the largest threat ever.

\section{REFERENCES}

\section{Solar power sources}

[1] Paris 2015: Tracking country climate pledges. Carbon Brief, https://www.carbonbrief.org/paris-2015tracking-country-climate-pledges 
[2] EDGAR v 4.3.2, European Commission, Joint Research Centre (JRC)/PBL Netherlands Environmental Assessment Agency. Emission Database for Global Atmospheric Research (EDGAR), release version 4.3.2. http://edgar.jrc.ec.europe.eu, 2016 forthcoming

[3] CO2 Emission Reduction With Solar http://www.solarmango.com/in/tools/solar-carbon-emissionreduction

\section{GDP Sources}

[4] World Bank national accounts data - data.worldbank.org

[5] OECD National Accounts data files

\section{GHG and energy sources:}

[6] World Resources Institute CAIT Climate Data Explorer - cait.wri.org

[7] EU Joint Research Centre Emission Database for Global Atmospheric

[8] Research - http://edgar.jrc.ec.europa.eu/overview.php

[9] UN Framework Convention on Climate Change -

[10] http://unfccc.int/ghg_data/ghg_data_unfccc/time_series_annex_i/items/3814.php

[11] International Energy Agency. Paris.

[12] Energy Information Administration. Washington, DC.

[13] BP Energy Outlook 2016.

[14] EU Emissions Database for Global Research EDGAR,

[15] http://edgar.jrc.ec.europa.eu/

[16] World Bank Data Indicators, data.worldbank.org

[17] British Petroleum Statistical Review of World Energy 2016.

\section{Literature}

[18] Conka, K. (2015) Un Unfinished Foundation. The United Nations and Global Environmental Governance. Oxford: OUP.

[19] Dutta, P.K. (1999) Games and Strategies. Cambridge, MA: MIT Press.

[20] 2007 Cool It: The Skeptical Environmentalist's Guide to Global Warming. Alfred A. Knopf.

[21] March, J.G. and J. P. Olsen (1976), Ambiguity and Choice in Organizations. Bergen, Norway: Universitetsforlaget.

[22] March, J.G. and Herbert A. Simon (1993), Organizations. New York: Wiley, 1958. 2nd ed., Oxford: Blackwell Publishers.

[23] Pressman, J. and Wildavsky, A. (1984) Implementation. Berkeley: University of Cal Press.

[24] Ramesh, J. (2015) Green Signals: Ecology, Growth and Democracy in India (2015). Oxford : Oxford University Press.

[25] Sachs, J.D. (2015) The Age of Sustainable Development. New York: Columbia University Press.

[26] Simon, H. Models of Man: Social and Rational (1957). New York: Wiley.

[27] Burchill, S., A. Linklater and R. Devetak (2013) Theories of International Relations. Macmillan Palgrave.

[28] Stern, N. (2007) The Economics of Climate Change. Oxford: OUP.

[29] Stern, N. (2015) What are we waiting for? Cambridge, MA: MIT Press.

[30] Vogler, J. (2016) Climate Change in World Politics. Basingstoke: MacmillanPalgrave.

[31] Searching for Safety. 1988. Transaction Books.

Citation: Jan-Erik Lane. "Climate Crisis and the "We”: An Essay in Deconstruction" International Journal of Managerial Studies and Research (IJMSR), vol 6, no. 5, 2018, pp. 34-43. doi:http://dx.doi.org/10.20431/ 2349-0349.0607004.

Copyright: () 2018 Authors. This is an open-access article distributed under the terms of the Creative Commons Attribution License, which permits unrestricted use, distribution, and reproduction in any medium, provided the original author and source are credited. 